\title{
Pengaruh Senam Lansia Terhadap Kebugaran Jasmani Warga Perumahan Pondok Pinang Kelurahan Lubuk Buaya Kecamatan Koto Tangah Kota Padang
}

\author{
Ali Mardius', Yuni Astuti2,* \\ 1 Jurusan Pendidikan Jasmani Kesehatan dan Rekreasi, Universitas Bung Hatta, Padang, Indonesia \\ ${ }_{2}^{2}$ Jurusan Pendidikan Jasmani Kesehatan dan Rekreasi, Universitas Bung Hatta, Padang, Indonesia
}

\begin{abstract}
Abstrak
Problems in this study are still many people who do not have good physical fitness. This study aims to determine the influence of elderly gymnastics on the physical fitness of residents Pondok Pinang Village Lubuk Buaya Sub-District Koto Tangah Padang City. The sample in this research is resident of lodge of pinang numbered as many as 18 people. The instrument used to measure people's physical fitness is 2.4 $\mathrm{km}$. Data were analyzed by using t-test different mean. Based on the results of data analysis, it was found that elderly gymnastics had a significant effect on physical fitness, because it was found thitung $=5.35>$ ttable $=2.11$ and it was proved that there was a difference of mean physical fitness before treatment (preliminary test) Is 22.58 and mean after treatment is given (final test) is 18,73 , it means there is increase 3,85 to physical fitness.
\end{abstract}

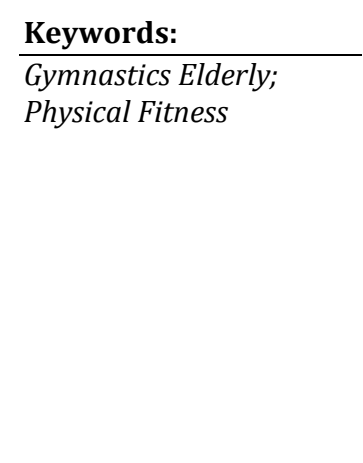

\section{Pendahuluan}

Pada saat memasuki usia lanjut, fungsi-fungsi tubuh tidak dapat lagi berfungsi dengan baik, maka lansia membutuhkan banyak bantuan dalam menjalani aktivitas-aktivitas kehidupannya. Belum lagi berbagai penyakit yang menyertai keadaan lansia yang membuat mereka memerlukan perhatian ekstra dari orang-orang di sekelilingnya. Aktivitas olahraga akan membantu tubuh tetap bugar dan segar karena melatih tulang tetap kuat, mendorong jantung bekerja optimal, dan membantu menghilangkan radikal bebas yang berkeliaran di dalam tubuh, dengan kata lain mempunyai kebugaran jasmani yang baik bila jantung dan peredaran darah baik sehingga seluruh tubuh dapat menjalankan fungsinya dalam waktu yang cukup lama.

Berkaitan dengan kebugaran jasmani yang dikatakan sebagai kemampuan yang dimiliki untuk tetap bisa melakukan aktivitas tanpa mengalami kelelahan yang berarti, kebugaran jasmani pada seseorang memiliki fungsi yang berperan sebagai penunjang kualitas aktivitas yang dilakukan. Berdasarkan fungsinya menurut Ismaryati (2009) kebugaran jasmani dikelompokan menjadi dua yaitu umum dan khusus. Fungsi umum adalah untuk mengembangkan kekuatan, kemampuan, kesanggupan, daya kreasi dan daya tahan setiap manusia untuk mempertinggi daya kerja. Fungsi khusus adalah sesuai kekhususan masing- masing sesuai pekerjaan (misalnya: atlet, pelajar, pekerja kantoran), keadaan (misalnya: ibu hamil) dan umur (misalnya: bagi anak untuk merangsang pertumbuhan dan bagi lansia untuk mempertinggi ketahanan tubuh).

Pentingnya kebugaran jasmani yang baik untuk menunjang aktivitas kerja terutama masyarakat yang sudah memasuki usia lanjut yang. Untuk mempertahankan dan meningkatkan kebugaran jasmani tersebut dapat dilakukan dengan cara melakukan olahraga yang teratur dengan frekuensi latihan 3 - 5 kali perminggu dengan latihan minimal 15 sampai 25 menit. Jenis olahraga bagi lansia untuk mencapai ketahanan tubuh dengan kebugaran yang paling tepat adalah latihan senam yang disertai latihan-latihan kekuatan ditambah gerakan keseimbangan dan peregangan. Melaksanakan latihan senam dengan rutin akan meningkatkan efisien paru-paru dan kerja jantung, aktivitas bermanfaat untuk meningkatkan dan mempertahankan katahanan kardiorespiratori (jantung paru-peredaran darah). Untuk meningkatkan kebugaran jasmani harus memenuhi prinsip dasar yaitu frekuensi, intensitas, dan durasi latihan. Konsep dasar dalam pelaksanaan olahraga senam ini harus melibatkan gerak otot-otot besar pada panggul dan kaki secara ritmis atau melibatkan tungkai dan tangan, serta pinggang, punggung dan perut, sehingga dapat memacu sistem kardiorespirasi. 
Berdasarkan hal tersebut, penulis akan melakukan penelitian untuk mengetahui pengaruh senam lansia terhadap kebugaran jasmani lansia warga Perumahan Pondok Pinang Kelurahan Lubuh Buaya Kecamatan Koto Tangah Kota Padang. Penulis akan mengidentifikasi pengaruh dari pelaksanaan senam lansia terhadap kebugaran jasmani lansia. Berdasarkan latar belakang masalah di atas, maka yang menjadi permasalahan akan diteliti yaitu apakah ada pengaruh senam lansia terhadap peningkatan kebugaran jasmani lansia warga perumahan Pondok Pinang Kelurahan Lubuk Buaya Kecamatan Koto Tangah Kota Padang.

Kebugaran jasmani merupakan kondisi individu dari kebugaran menyeluruh (total fittness) yang memberikan kasanggupan kepada seseorang untuk menjalankan hidup yang produktif dan dapat menyesuaikan pada tiap pembebanan atau stress fisik yang layak" (Mutohir dkk, 2004:160) mengatakan bahwa. Sedangkan menurut Sri Wahyu Ningsih Nugraheni (2013:34) "Kebugaran jasmani merupakan salah satu tolak ukur kesehatan masyarakat setiap kelompok masyarakat termasuk lansia. Lansia yang memiliki kebugaran jasmani yang tinggi selain sehat dan segar juga dapat melakukan aktivitas seharihari secara mandiri. Kebugaran jasmani yang buruk pada lansia sering membuat lansia terlihat tidak sehat dan sering mengalami cedera akibat terjatuh. Proses menua tidak dapat dihindari oleh semua orang. Proses penuaan sering disertai oleh adanya peningkatan gangguan organ dan fungsi tubuh, terjadi perubahan komposisi tubuh, terjadi penurunan massa bebas lemak dan peningkatan massa lemak. Pada proses penuaan ini prosentase massa otot menurun. Kekuatan otot pada lansia juga berhubungan dengan masalah terjadinya keseimbangan yang mempunyai resiko lansia mudah terjatuh". Salah satu cara untuk meningkatkan kebugaran jasmani warga yaitu dengan memberikan perlakuan dengan senam lansia.

Senam lansia adalah serangkaian gerak nada yang teratur, terarah serta terencana dalam bentuk latihan fisik yang berpengaruh terhadap latihan fisik lansia. Olahraga yang cocok bagi lansia adalah senam yang disebut dengan senam lansia. Pengertian dari senam lansia adalah serangkaian gerakan nama yang terarah dan teratur dan kemudian diikuti oleh para lanjut usia yang pelaksanaannya dimaksudkan untuk meningkatkan kemampuan raga secara fungsional. Senam lansia dirancang khusus guna melatih bagian tubuh, pinggang, kaki, dan tangan untuk mendapatkan peregangan untuk para lansia, akan tetapi gerakan tersebut tidak boleh berlebihan. Apabila diperhatikan, senam lansia membuat pesertanya tidak banyak bergerak layaknya olahraga aerobik. Semua jenis senam dan aktivitas olahraga ringan tersebut, sangat bermanfaat untuk menghambat proses degeneratif atau proses penuaan. Senam ini sangat dianjurkan untuk mereka yang memasuki usia lansia 46 tahun ke atas. Senam lansia disamping memiliki dampak positif terhadap peningkatan fungsi organ tubuh juga dapat berpengaruh dalam peningkatan imunitas dalam tubuh manusia setelah latihan teratur. Kebugaran jasmani dievaluasi dengan cara mengawasi kecepatan denyut jantung waktu istirahat, yaitu kecepatan denyut nadi sewaktu istirahat. Penelitian menyebutkan bahwa agar tubuh menjadi lebih bugar, maka kecepatan denyut jantung sewaktu istirahat harus menurun

\section{Metode}

Penelitian ini akan dilaksanakan di Perumahan Pondok Pinang Kelurahan Lubuk Buaya Kecamatan Koto Tangah Kota Padang. Penelitian ini menggunakan model kuantititatif dengan pendekatan eksperimental semu. Tujuan dari eksperimentasl semu ini merupakan perkiraan bagi informasi yang dapat diperoleh dengan eksperimen yang sebenarnya dalam keadaan yang tidak memungkinkan untuk mengontrol atau memanipulasi semua variabel yang relevan, (Sunarno, 2011:56). Rancangan penelitian yang digunakan dalam penelitian ini yaitu eksperimental semu yang lebih spesifik yaitu one-group pretestposttest design yaitu rancangan penelitian dalam satu kelompok dengan mengadakan tes awal dan ters akhit setelah diberikan perlakuan. Teknik pengumpulan data yang digunakan yaitu tes lari 2,4 km. Teknik analisis data didalam langkah memilih pendekatan penelitian, telah dikemukan beberapa desain eksperimen diantaranya telah disertai rumus/cara analisis datanya. Untuk testing signifikansi, maka digunakan rumus $t$ - test. Secara garis besar, pekerjaan analisis data meliputi 3 langkah yaitu persiapan, tabulasi dan penerapan data sesuai dengan pendekatan penelitian

\section{Hasil dan Pembahasan}

Hasil tes awal kebugaran jasmani sebelum diberi perlakuan dengan senam lansia, yang dilakukan terhadap 18 orang warga, diperoleh rata-rata hitung (mean) adalah 22,58, standar deviasi adalah 3,78, skor tertinggi 14,18 dan skor terendah 28,44, sedangkan jarak pengukuran (range) adalah 14,26. Untuk lebih jelasnya distribusi frekuensi kategori tes awal kebugaran jasmani sebelum diberikan perlakukan dapat dilihat pada tabel dibawah ini: 
Tabel 1. Distribusi Frekuensi Kategori Tes Awal Kebugaran Jasmani Sebelum Diberikan Perlakuan Senam lansia

\begin{tabular}{|c|c|c|c|}
\hline Skor & Kategori & $\begin{array}{c}\text { Frekuensi } \\
\text { Absolut }\end{array}$ & $\begin{array}{c}\text { Frekuensi } \\
\text { Relatif }\end{array}$ \\
\hline$\leq 16,90$ & Baik Sekali & 2 & 11,11 \\
\hline $16,91-20,68$ & Baik & 2 & 11,11 \\
\hline $20,69-24,46$ & Sedang & 8 & 44,44 \\
\hline $24,47-28,24$ & Kurang & 5 & 27,78 \\
\hline$\geq 28,25$ & Kurang sekali & 1 & 5,56 \\
\hline & Jumlah & 18 & 100 \\
\hline
\end{tabular}

Berpedoman pada Tabel 1, maka dapat ditarik suatu kesimpulan bahwa dari 18 orang sampel, yang memiliki kebugaran jasmani kategori baik sekali dan kateagori baik masing-masing yaitu 2 orang $(11,11 \%)$. Sedangkan warga yang memiliki kebugaran jasmani kategori sedang yaitu sebanyak 8 orang $(44,44 \%)$ dan yang memiliki kebugaran jasmani kategori kurang yaitu 5 orang (27,78\%). Selanjutnya warga yang memiliki kebugaran jasmani kategori kurang sekali yaitu hanya 1 orang (5,56\%). Untuk lebih jelasnya histogram variabel kebugaran jasmani warga Perumahan Pondok Pinang di Kelurahan Lubuk Buaya Kecamatan Koto Tangah Kota Padang tersebut dapat dilihat pada gambar 1 di bawah ini.

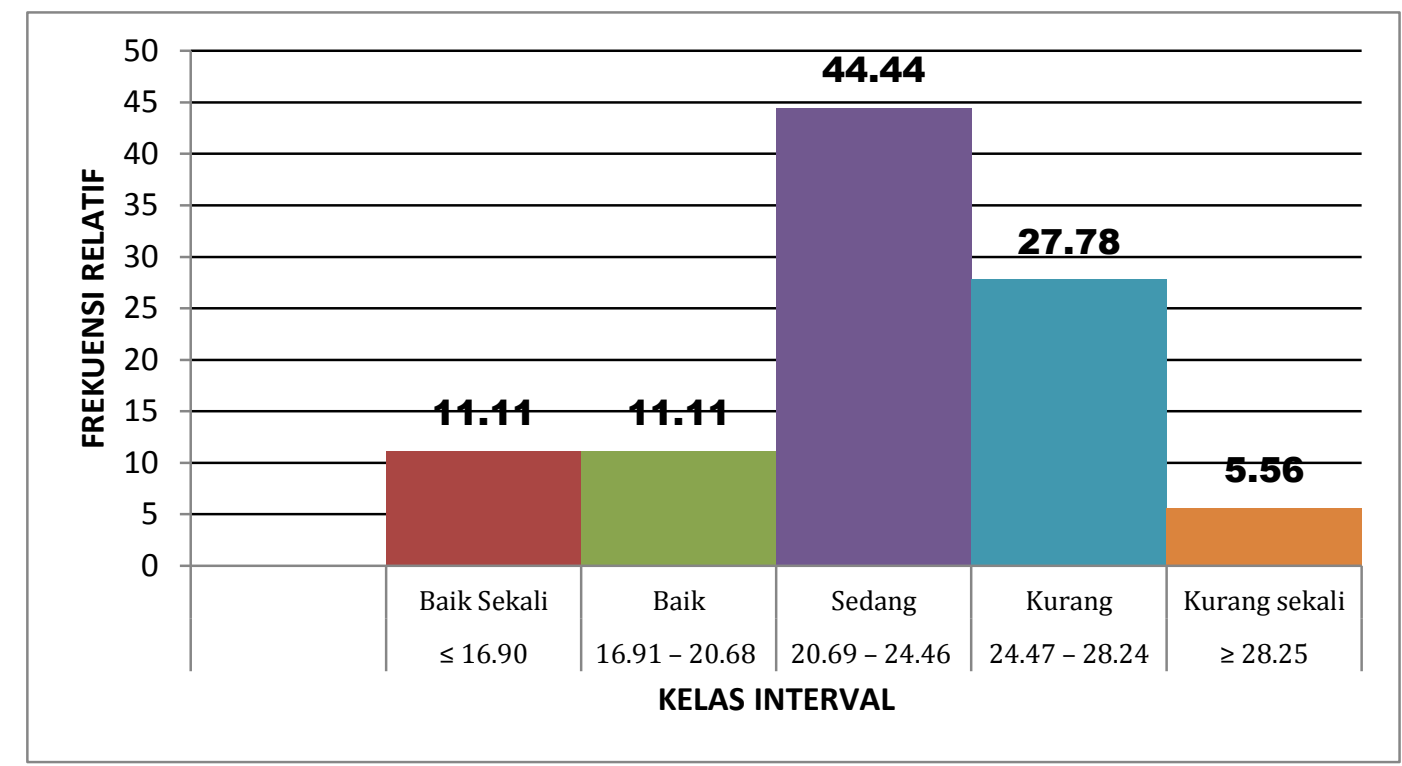

Gambar 1. Histogram Tes Awal Kebugaran Jasmani Sebelum Diberikan Perlakuan Senam Lansia

Berdasarkan uraian penskoran tentang variabel kebugaran jasmani dari 18 orang warga Perumahan Pondok Pinang di Kelurahan Lubuk Buaya Kecamatan Koto Tangah Kota Padang, sebelum diberi perlakuan yang telah dikemukakan di atas, maka ditemukan yang berada pada skor kelompok di atas rata-rata yaitu sebanyak 10 orang (55,56\%) dan skor dalam kelompok rata-rata tidak ada satu orangpun yang memilikinya. Sedangkan untuk di bawah skor rata-rata ditemukan 8 orang $(44,44 \%)$.

Selanjutnya dari hasil tes akhir kebugaran jasmani yang dilakukan terhadap 18 orang warga setelah diberikan perlakuan senam lansia, diperoleh rata-rata hitung (mean) adalah 18,73, standar deviasi adalah 1,71, skor tertinggi adalah 14,31 dan skor terendah yaitu 20,29. Sedangkan jarak pengukuran (range) adalah 5,98. Selanjutnya distribusi kategori kebugaran jasmani warga Perumahan Pondok Pinang di Kelurahan Lubuk Buaya, setelah diberikan perlakuan senam lansia dapat dilihat pada tabel 2. 
Tabel 2. Distribusi Frekuensi Kategori Kebugaran Jasmani Setelah Diberikan Perlakuan Senam lansia

\begin{tabular}{|c|c|c|c|}
\hline Skor & Kategori & $\begin{array}{c}\text { Frekuensi } \\
\text { Absolut }\end{array}$ & $\begin{array}{c}\text { Frekuensi } \\
\text { Relatif }\end{array}$ \\
\hline$\leq 16,15$ & Baik Sekali & 1 & 5,56 \\
\hline $16,16-17,86$ & Baik & 3 & 16,67 \\
\hline $17,87-19,57$ & Sedang & 7 & 38,89 \\
\hline $19,58-21,28$ & Kurang & 7 & 38,89 \\
\hline$\geq 21,29$ & Kurang sekali & 0 & 0 \\
\hline & Jumlah & $\mathbf{1 8}$ & $\mathbf{1 0 0}$ \\
\hline
\end{tabular}

Berdasarkan pada Tabel 2, maka jelaslah bahwa dari 18 orang warga yang memiliki kebugaran jasmani kategori baik sekali yaitu hanya 1 orang (5,56\%), untuk kategori kebugaran jasmani baik yaitu ada 3 orang $(16,67 \%)$ dan kategori sedang yakni sebanyak 7 orang $(38,89 \%)$. Sedangkan warga yang memiliki kebugaran jasmani kategori kurang juga ada sebanyak 7 orang (38,89\%) dan kategori kurang sekali tidak ada warga yang memilikiya. Untuk lebih jelasnya histogram variabel tes akhir kebugaran jasmani warga Perumahan Pondok Pinang di Kelurahan Lubuk Buaya Kecamatan Koto Tangah Kota Padang, setelah diberikan perlakuan Senam lansia tersebut dapat dilihat pada gambar 3 di bawah ini.

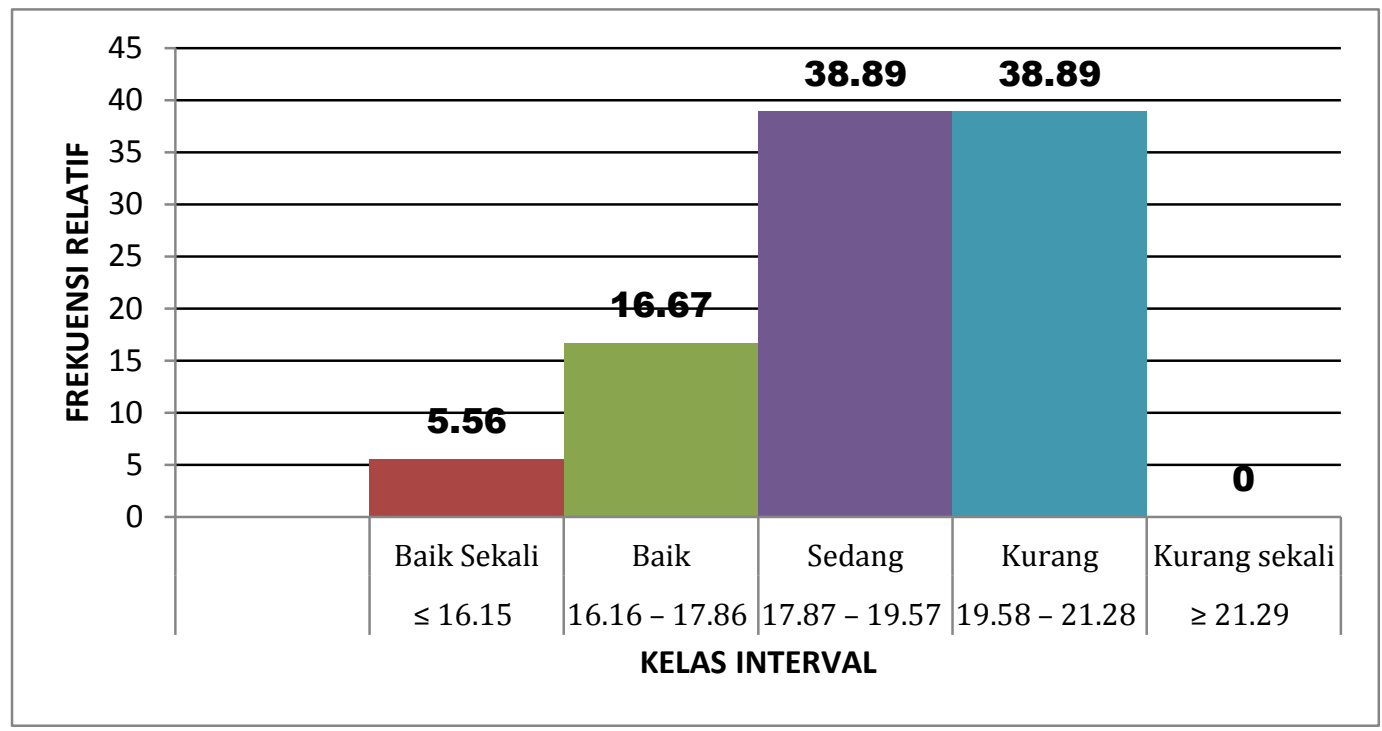

Gambar 3. Histogram Tes Akhir Kebugaran Jasmani Setelah Diberikan Perlakuan Senam Lansia

Berdasarkan uraian penskoran tentang variabel kebugaran jasmani warga Perumahan Pondok Pinang di Kelurahan Lubuk Buaya Kecamatan Koto Tangah Kota Padang, sesudah diberikan perlakuan Senam lansia yang telah dikemukakan di atas, maka ditemukan warga yang berada di atas kelompok ratarata adalah 6 orang (33,33\%) dan skor dalam kelompok rata-rata tidak ada satu orangpun yang memilikinya. Sedangkan untuk di bawah skor rata-rata ditemukan sebanyak 12 orang $(66,67 \%)$.

Hasil analisis data ditemukan bahwa terdapat pengaruh yang signifikan senam lansia terhadap kebugaran jasmani warga Perumahan Pondok Pinang di Kelurahan Lubuk Buaya Kecamatan Koto Tangah Kota Padang. Untuk menguji koefisien hipotesis digunakan rumus uji beda mean atau Uji - t. Sedangkan untuk menentukan apakah kofisien $t$ yang diperoleh dengan rumus thitung tersebut signifikan atau tidak maka dibandingkan dengan rumus tabel. Hasil analisis koefisien pengaruh senam lansia terhadap kebugaran jasmani diperoleh $t_{\text {hitung }}=5,35>t_{\text {tabel }}=2,11$. Dengan demikian dapat disimpulkan bahwa apabila nilai yang diperoleh dari thitung lebih besar dari pada nilai yang diperoleh dari tabel maka hipotesis yang diajukan di dalam penelitian ini diterima kebenarannya secara empiris, yakni terdapat pengaruh senam lansia terhadap kebugaran jasmani warga Perumahan Pondok Pinang di Kelurahan Lubuk Buaya Kecamatan Koto Tangah Kota Padang.

Dari temuan hasil penelitian yang telah dijelaskan di atas, maka dapat diartikan bahwa senam lansia dapat memberikan pengaruh terhadap peningkatan kebugaran jasmani warga Perumahan Pondok Pinang di Kelurahan Lubuk Buaya Kecamatan Koto Tangah Kota Padang. Hasil analisis data menunjukkan bahwa nilai rata-rata (mean) kelompok kebugaran jasmani sebelum diberikan perlakuan (tes awal) 
adalah 22,58 dan nilai rata-rata (mean) sesudah diberikan perlakuan (tes akhir) dengan melakukan senam lansia adalah 18,73, artinya terjadi peningkatan sebesar 3,85 terhadap peningkatan kebugaran jasmani.

Berpedoman dari uraian di atas, maka jelaslah bahwa dengan memberikan perlakuan atau treatment dengan senam lansia kepada warga Perumahan Pondok Pinang di Kelurahan Lubuk Buaya Kecamatan Koto Tangah Kota Padang dapat meningkatkan kebugaran jasmani warga. Meskipun peningkatan kebugaran jasmani warga tidak terlalu tinggi, namun latihan senam lansia jelas memberikan pengaruh secara signifikan terhadap peningkatan kebugaran jasmani warga. Selanjutnya dapat dikatakan hal ini merupakan salah satu upaya yang dapat dilakukan warga di tempat tinggal untuk mengadakan secara rutin atau continue dalam melakukan senam tersebut. Di samping itu dengan membiasakan warga untuk bisa mengikuti kegiatan senam lansia di pagi hari, secara teratur dengan melakukan gerakan yang benar dan berkesinambungan, ini dapat menanamkan kebiasaan berolahraga pada warga. Dinata (2002) mengemukakan bahwa: "senam adalah rangkaian gerak yang dipilih secara sengaja dengan cara mengikuti irama musik yang juga dipilih sehingga melahirkan ketentuan ritmis, kontinuitas dan durasi tertentu".

Kebugaran jasmani sangat penting bagi warga karena kebugaran jasmani ditinjau dari ilmu faal (fisiologi) adalah "kesanggupan dan kemampuan tubuh melakukan penyesuaian terhadap pembebanan fisik yang diberikan kepadanya (dari kerja yang dilakukan sehari-hari tanpa menimbulkan kelelahan yang berlebihan, hal ini dikemukakan oleh Depdiknas (2000:53). Apabila warga yang memiliki tingkat kebugaran jasmani baik, akan mempunyai kemampuan untuk menyelesaikan pembebanan fisik, misalnya tugas-tugas fisik seperti aktivitas melakukan pekerjaan rumah yang begitu banyak maka seseorang tidak akan mengalami kelelahan yang berarti. Meskipun senam lansia memberikan pengaruh terhadap peningkatan kebugaran jasmani warga Perumahan Pondok Pinang di Kelurahan Lubuk Buaya Kecamatan Koto Tangah Kota Padang, akan tetapi masih banyak faktor yang dapat mempengaruhi tingkat kebugaran jasmani warga untuk lebih baik dan lebih besar peningkatannya. Faktor tersebut antara lain status gizi, usia, istirahat yang cukup kebiasaan warga dalam beraktivitas seperti aktivitas fisik setiap hari. Di samping itu lingkungan yang bersih dan kebersihan pribadi dapat mempengaruhi kebugaran jasmani warga, terutama lingkungan tempat tinggal dan kebiasaan hidup sehat setiap hari.

\section{Simpulan dan Saran}

\section{Simpulan}

Berdasarkan kepada hasil analisis dan pembahasan yang telah diuraikan pada bagian terdahulu, maka pada bab ini dapat diambil kesimpulan yaitu: Senam lansia memberikan pengaruh yang signifikan terhadap kebugaran jasmani, karena ditemukan $t_{\text {hitung }}=5,35>t_{\text {tabel }}=2,11$ dan terbukti adanya perbedaan nilai rata-rata (mean) kebugaran jasmani sebelum diberikan perlakuan (tes awal) adalah 22,58 dan mean sesudah diberikan perlakuan (tes akhir) adalah 18,73, artinya terjadi peningkatan sebesar 3,85 terhadap kebugaran jasmani.

\section{Saran}

Berdasarkan kepada kesimpulan yang telah dikemukakan di atas, maka disarankan kepada:

1. Masyarakat Perumahan Pondok Pinang agar melakukan latihan fisik untuk menjaga kebugaran jasmaninya dengan melakukan latihan senam secara rutin sehingga dengan kebugaran jasmani yang baik tersebut juga dapat menghindari berbagai macam penyakit.

2. Ketua Rukun Warga, agar mengadakan agenda rutin untuk warga baik itu untuk laki-laki maupun Perempuan untuk melakukan kegiatan yang dapat menjaga kebugaran jasmaninya sehingga dengan tubuh yang bugar maka produktifitas kerja warga juga meningkat dan warga juga memiliki tubuh yang sehat.

\section{Daftar Rujukan}

Azizin Irhas. 2014. Hubungan Status Gizi dan Aktivitas Fisik Dengan Tingkat Kebugaran Jasmani Warga Sekolah Dasar (studi pada warga Kelas IV dan V MI AL Hikmah Gempolmanis. Semarang: Jurnal Kesehatan Olahraga Ikor FIK UNESA. 2 (2) : 18.

Depkes R.I, 2002. Pedoman Pemberantasan Penyakit Infeksi Saluran Pernafasan Akut Untuk Penanggulangan Pneumonia Pada Balita, Ditjen PPM-PLP. Jakarta.

Ismaryati. 2009. Tes Pengukuran Olahraga. Surakarta: Sebelas Maret University Press.

Mutohir, T.Cholik. 2004. Perkembangan Motorik Pada Masa Anak-anak. Jakarta: Dirjen Olahraga, Depdiknas. 
Nugraheni Sriwahyu Ningsih. 2013. Faktor-Faktor Yang Berhubungan Dengan Tingkat Kebugaran Jasmani Pada Lansia di Panti Wreda Dharma Bhakti. Surakarta: Jurnal Infokes. 3 (1) : 34.

Rosmalina Yuniar, dkk. 2003. Faktor-Faktor Yang Berhubungan Dengan Tingkat Kebugaran Jasmani Lansia Laki-Laki Tidak Anemia. Jakarta: Jurnal PGM. 26 (1) : 11.

Sugiyono. 2008. Metode Penelitian Pendidikan. Bandung: Alfabeta.

Sunarno Agung. 2011. Metode Penelitian Keolahragaan. Surakarta: Yuma Pustaka. 